INTERNATIONAL JOURNAL OF

ORGANIZATIONAL LEADERSHIP

WWW.CIKD.CA

\title{
The Leadership Process in Teacher Education: A Case Study at the University of Lisbon
}

\author{
Ana Luísa Rodrigues
}

Instituto de Educação, Universidade de Lisboa

\section{Keywords:}

Leadership, Supervision,

Preservice teacher education,

Economics education,

Accounting education

Received

08 May 2020

Received in revised form

21 May 2020

Accepted

14 June 2020

\begin{abstract}
The leadership and pedagogical supervision process in teacher education is a crucial issue for the training pedagogical quality and teachers' professional development. The relationship that is necessary to establish between the Higher Education Institution and the Cooperating Schools where the supervised pedagogical practice is carried out is crucial. In this study we analyze this process of shared leadership and supervision, understanding this relationship from a perspective of effective collaboration, reflexivity and sharing of practices between various contributors - the preservice teacher, the university professor and the mentor teacher. Based on this premise, we shall analyze the importance of leadership in an educational context and the role of supervision for the improvement of organizational and teaching-learning situations and experiences. The aim of this study is to promote autonomy and shared interaction, contributing to professional development and knowledge co-construction. In methodological terms, this is a case study, within the scope of the Master in Teaching of Economics and Accounting at the Institute of Education, University of Lisbon, the only master's degree in Portugal that provides a professional qualification for teaching in secondary education in the area of Economics and Accounting. This study intends to obtain a characterization of the leadership and supervision process developed, to reflect on appropriate leadership theories in educational context and to outline the main functions of the mentor teacher as a fundamental part of the collaborative supervision process, framed in the current model of teacher training in Portugal.
\end{abstract}




\section{Introduction}

Pedagogical supervision, in preservice teacher education models, is widely accepted as a standard and fundamental procedure, essential for teachers who start in the profession (Ginkel, Drie, \& Verloop, 2018). It is a process that normally brings strong contributions to the construction of the future teacher's professional identity (Izadinia, 2015). In this sense, this study aims to analyze the process of leadership and supervision in teacher education, during which collaboration, reflection and sharing of practices between the various contributors is required, including the university professor. Above all, the focus is on the relationship between the mentor teacher from the cooperating school and the preservice teacher, since the success of the process depends largely on the diagnostic capacities, relationship and performance of the mentor teacher (Ginkel et al., 2018). Within this process, the evaluation is a complementary and indispensable component. In this case, the aim is to assign importance to formative assessment, based on the assumption that collaboration can enhance the reflection and professional development of teachers, and provide mutual teaching, assessment and learning situations. Thus, based on a case study, with participant observation in a Master's Degree in Teaching at the University of Lisbon, we intend to characterize the process of supervision and leadership, reflect on theories of leadership in the educational context and outline the main functions of the mentor teacher as a fundamental part of the collaborative supervision process.

\section{Leadership and Pedagogical Supervision Process in Preservice Teacher Education}

Approaching the topic of pedagogical supervision, we found the term "clinical practice" underlying. In addition to the parallel that can be established with the medical field, this concept mainly aims to highlight particular characteristics attributed to professional training (Burn \& Mutton, 2015). In this sense, these authors consider that preservice teacher education programs should not be interpreted merely as spaces to learn through experience or by imitation of the more experienced teachers, with pre-specified classroom routines. "Clinical practice" presupposes that preservice teachers engage in a research process based on various sources of knowledge including search and data collection in order to acquire interpreting skills, in particular, the intervention and implementation of pedagogical actions and evaluation of results.

Nonetheless, Mena, Hennissen, and Loughran (2017) point to the importance of self-learning through experience in knowledge acquisition, in relation to learning through the guidance of more experienced teachers. However, they consider that the support of these mentor teachers is crucial in the knowledge of the practice and professional development of the teachers in formation. They found that the level of participation of the mentor teachers in the creation of knowledge was generally high, which may indicate the relevance of the first experiences of the preservice teachers and how their learning can be promoted through the advice of the experienced teachers. It is also suggested that less directivity of these, offers greater opportunity for preservice teachers to acquire higher level knowledge.

On the other hand, Izadinia (2015) found that, although mentor teachers did not create very significant changes in the professional identity of the preservice teachers, they can influence them positively or negatively. In this way, when the orientation relationship is positive and the expectations of the preservice teachers are reached, they tend to obtain a higher level of confidence in their capacities as a teacher, which can have a significant impact on the construction of their professional identity. 
According to Vieira and Moreira (2001), some supervision strategies can be mobilized such as self-questioning or self-assessment, reflective dialogue, documentary analysis, inquiry, observation of classes, professional narratives, teaching portfolio and action research; which correspond to the following data collection methods: questionnaires, field notes, reflective records, audio and video recordings, grids and scripts.

One of the strategies most used in preservice teacher education programs around the world is peer coaching, aiming to improve teachers' professional practices and development (Lu, 2010). In this case, from an expert coaching perspective, more experienced teachers support teachers in training (Ackland, 1991, as sited in Lu, 2010). In this strategy, class observation is very important, which normally includes three main phases: pre-observation, observation and post-observation, where time is required for teachers to observe before and after class in order to make the observation cycle operational. Lu (2010) stated that for the development of this strategy, it is important to guarantee three conditions: a) a programmatic vision that believes in the strategy potential for the development of future teachers, b) an organized, balanced and significant program, and c) an implementation phase followed by constant evaluation.

Regarding the evaluative issue associated with the pedagogical supervision process, some relevant ethical guidelines are also highlighted. These allow us to support procedures for a fair assessment. These should obey the following principles: rigor about the normative framework, principles and objectives; clarification on the role of each player involved in the assessment relationship; diversification of observation and information collection strategies; and transparency in the presentation and use of the collected information, based on intelligibility schemes of practical knowledge (Batista, 2011).

\section{Teacher Leadership Value}

The concept of leadership in the educational context should be introduced as early as initial training. Teacher education programs, under the guidance of mentor teachers, are the ideal place to start developing the knowledge and skills of teachers in training by offering them a reference of leadership framework (Bond, 2011). By starting this process at the beginning of their career, they will be better prepared to assume increasingly consistent roles at the level of leadership throughout their professional lives.

For a successful construction and development of leadership skills by the teacher, this must be a deliberate and carefully planned process (Muijs \& Harris, 2007). These authors, in a study on teacher leadership, suggest that it was more effective in cases where it had been strategically implemented through changing structures and school culture. They found the importance of a cultural change in the organization's vision and values, requiring that all stakeholders understand and want to be involved in leadership activities. In other words, it is necessary that the leadership is deeply rooted in the culture of the schools, with the role of the Principal assuming an added importance, namely in the decision to distribute the leadership functions. This study also concluded that it is essential that teachers are willing and sufficiently qualified to assume leadership roles, which implies an investment of time and resources.

Forster (1997) also corroborates that leadership is one of the fundamental functions of a teacher's role and teacher education institutions should take particular responsibility, preparing teachers not only to understand the concept of leadership, but to be able to effectively experience the ability and develop the associated skills. 
In preservice teacher education, to promote change and the construction and development of leadership skills, teacher educators need to be offered a solid theoretical basis associated with teacher leadership because theory allows one support and explain thinking about the study of a phenomenon and provides a justification for the action. The three theories most frequently mentioned in the literature of leadership for teacher education include distributed, transformational and servant leadership (Bond, 2011).

\section{Distributed Leadership}

The theory of distributed leadership comes up against the traditional model of leadership, advocating that decision making, responsibility and authority should be distributed among leaders both formal and informal (Bond, 2011). It argues that working together in a distributed way produces a better result than working alone. In other words, it aims to promote collaborative work and the responsibility assumed collectively, considering that it can be exercised by anyone within the organization at any time and situation. This distributed leadership theory can be difficult to implement today in many public schools due to its hierarchical and organizational nature which is not very flexible. However, in the face of possible changes in the short term it is important to prepare preservice teachers for greater collaboration and the possibility of assuming leadership responsibilities in the future.

Due to the increased complexity and lack of teamwork in different organizational contexts, namely in educational institutions, we are faced with the need to move from vertical to shared leadership (Pearce, 2004), to the extent that the latter is shown as an important potential factor to explain the team's effectiveness (Pearce \& Sims, 2002) and offers a concept of implementing leadership as a team-level phenomenon (Pearce \& Conger, 2003). Also, in the pedagogical supervision process, we can observe the advantages of shared leadership between the university professor and the mentor teacher, mainly with regard to their contribution for the professional development along with benefits for the future teacher through receiving more demanding and rigorous feedback.

To facilitate this process of change, at least three major organizational systems need to be taken into account in distributed leadership training, reward, and cultural systems (Pearce, 2004). Sufficient leadership training is rarely provided with leadership issues being one of the aspects of organizational dissatisfaction for many employees. This training should focus on how to engage in responsible and constructive leadership, foster motivation and develop teamwork skills. Reward systems would also be important, whether individually or by team, despite being underused. Normally, one works mainly on the basis of feedback to improve performance or to determine the rewards for career advancements. Culture is a present component in organizations with a strong influence on employees, but often unconscious, so representing any change implemented is a considerable challenge.

The use of distributed leadership in the educational field has increased, and several studies suggest that it may be related to changes in academic competences. Consequently, with the growth of student learning, despite the implementation difficulties that can be found in structures with greater authority and hierarchy, distributed leadership can be seen as a threat to the instituted power (Bush \& Glover, 2014).

According to Pearce and Sims (2002), in shared leadership contexts, agents of influence are often peers of targets of influence and can play an important role in the dynamics and effectiveness of 
the team, and it can be claimed that shared leadership is significantly suitable for incorporation into leadership and teamwork training programs. In turn, one of the most important types of leadership behavior that can emanate from both vertical and shared leadership is transformational leadership (Pearce, 2004).

\section{Transformational Leadership}

Transformational leadership is one of the most effective leadership models in the field of education and training management, and very oriented towards change (Berkovich, 2016). According to several studies, it appears that this leadership model has a positive impact on specific educational results, mainly regarding the effectiveness of leaders, general satisfaction of teachers and student progress (Ebrahimi, Chamanzamin, Roohbakhsh, \& Shaygan, 2017). Kaslow, Falender, and Grus (2012) consider that transformational leadership is justified when a change in culture, educational and training climate is desired by ensuring a consistent and comprehensive implementation of a competency-based approach for clinical supervision. Current leadership trends, many originating in the field of organizational development, point to the fact that leadership skills are essential, despite the process of change being challenging. Transformational leadership aims to encourage innovative thinking or proactive planning, requiring social skills to mobilize people around a robust culture with a high level of interpersonal trust, openness and group cohesion. Thus, this theory of transformational leadership can help teacher leaders to initiate changing, providing democratic participation, identifying teachers as agents of change (Fullan, 1993).

According to Bond (2011), the transformational leader delegates projects to involve and create positive learning experiences, pays attention to the needs of the followers, and treats each person with respect. It can also intellectually involve others, proposing ideas that challenge the status quo and old ways of thinking. Those being led are guided to examine problems from different perspectives and to seek innovative solutions. When acquiring knowledge about transformational leadership theory, preservice teachers are provided with the understanding that one of the goals of education is to promote positive changes in other peoples' lives. In this way, supervising teachers take an active role in promoting social and collaborative skills in the preservice teachers, helping them to develop innovative teaching-learning processes with an impact on students and their results. The widespread use of the theory of transformational leadership in the educational context cannot be separated from the current environment, which is highly oriented towards changes in the level of educational policies, which emphasizes transformation and innovation to meet the growing demands of education systems (Berkovich, 2016).

It is also added that this theory seems to have a positive influence on the relationship with teacher job satisfaction and above all on the perception of their professional development. In turn, this degree of teacher satisfaction has a decisive effect on their lives as the investigation shows a strong correlation of this with the students' performance and progress (Zacharo, Marios, \& Dimitra, 2018).

\section{Servant Leadership}

One of the most adequate theories of leadership for preservice teacher education is the so-called servant leadership. This takes as a starting point of the natural feeling of serving and supporting the needs of the other and only afterwards does the aspect of needs as a leader emerges (Greenleaf, 1977). This theory advocates that a person values more serving and guiding, with the moral principle emerging, leaving the leadership component for a later plan. In practice, the teacher's 
commitment as a leader will not be so much to control the work of others, but to inspire creative energy in students and colleagues. In this sense, servant leadership in the educational context initially involves internal growth processes followed by external organizational effects (Bowman, 2005). Thus, servant leaders must be aware of their needs, of themselves and others, and demonstrate a commitment to growth. This theory holds significant relevance for teacher leaders of initial training because it implies placing the needs of others ahead of one's own needs, taking into account that teachers often enter the profession as a way to contribute to society and serve the community (Bond, 2011).

In this case, the personal development and motivation of the followers is emphasized, for instance, when the mentor teachers say "I will go; follow me!" (Greenleaf, 2007, p. 84), providing the ideas and the structure to accept failures in view of the possibility of success. In this way, it is considered that organizational goals will be achieved in the long term, initially based on professional growth and development, together with the general well-being of individuals (Stone, Russell, \& Patterson, 2004).

Laub (2004) defines the main areas of performance of servant leadership, which include the promotion of valuing and developing people, building a community, the practice of authenticity, shared leadership at the service of preservice teachers for the good of each individual, global organization, and beneficiaries of the organization. Thus, in this leadership process, people are valued along with their development as the support and sharing of leadership. However, for Greenleaf (2007), the vast majority of activities at the leadership level consist of the daily interaction of leaders and followers. In which, the crucial point of moral leadership is the ability to transcend the demands of the multiplicity of desires, needs and expectations, to respond to the highest levels of moral development and to relate the behavior of the leadership, namely their roles, choices and styles, to a set of conscious, explicit and grounded values.

Servant leadership can be distinguished from other perspectives by: a) an understanding and practice of leadership that requires a change in mentality or paradigm, more "parental" as opposed to an autocratic leader who leads by himself over others, b) it requires a different focus, in which it puts the good of the followers ahead, leaving the wishes of the leader, organizational interests and even the beneficiaries of the organization in a peripheral category, and c) the leader's self-interest, which recognizes the critical dimension of the leadership process itself, that is, although leaders are aware of this interest and the reality of organizational needs, they intentionally put the well-being of their followers as their main concern, to the detriment their own interests (Laub, 2004).

Stone et al. (2004) analyzed the similarities and differences between transformational leadership and servant leadership, concluding that both offer a conceptual framework for dynamic leadership, although they present differences mainly in relation to the leader focus. In the case of transformational leadership, this is directed towards the organization and the organizational objectives, while the focus of the servant leader is centered on the subordinates, with the achievement of organizational objectives as a consequent result.

Cerit (2009) also compared some of the perspectives and criticisms in the literature about transformational leadership and servant leadership. There are authors who consider that they are not distinct, and others who distinguish them, namely in the priority that is given to those led in servant leadership that may not be so present in transformational leadership, as well as, in the greater weight of the moral dimension and concern with the emotional well-being of those being led in servant leadership. In this measure, the same author adds that, while servant leaders have 
more pronounced feelings of altruism and equality, and focus on the needs of those led by overlapping organizational success, transformational leaders are more motivated by the organization's success and achievements. Both theories show concern in terms of the professional development of the participants, despite taking different paths, either through the emphasis on people or on organizational objectives.

Regarding the comparison with distributed leadership, it favors the organizational value, skills and motivation of people, instead of the desire to serve others which is very present in the servant leadership, although both emphasize collaboration and role sharing. Servant leadership values more ethical and moral issues together with people compared with personal growth and the potential development of employees, than distributed leadership, which considers leadership roles, structures, routines and functions more important. Considering servant leadership more comprehensive than distributed leadership, particularly because education is constituted with a moral purpose, servant leadership based on moral principles is a preferable approach in the educational context (Cerit, 2009).

\section{The Role and Functions of the Mentor Teacher}

Following a functional approach, leadership in an educational context can be divided into three categories according to Katzenmeyer and Moller (2009): a) leadership of students and colleagues, with the teacher acting as a facilitator, coach or specialist, namely with regard to curriculum development, with new instructional approaches or guidance from study groups, b) leadership of operational tasks such as keeping the school organized and fulfilling its objectives through functions, for example, as department or project coordinator, and c) leadership by decision-making or partnerships, which involves the participation of teachers in teams, with the function of promoting school improvements or intermediating partnerships with companies, higher education institutions and associations.

In the preservice teacher education, the mentor teacher assumes a role of intermediation and cooperation with the Higher Education Institution (HEI), which is one of the key elements of this leadership process. In this process of pedagogical supervision, it is intended to promote the reflective and collaborative capacity so that teachers to perform this function, contribute to the autonomy of preservice teachers and the construction of professional knowledge and the improvement of the quality of teaching (Azevedo, 2012).

Mentor teachers are key actors in the preparation of preservice teachers for the teaching profession, being recognized for their knowledge of teaching praxis complemented with the theoretical knowledge acquired through academic qualifications (Maphalala, 2013). Thus, it is understood that mentor teachers' role includes facilitating the student's socialization in the teaching profession, helping them to acquire skills in the various areas of school functioning such as in planning and teaching classes, classroom management and proper use of teaching-learning strategies and resources.

Vieira (1993) describes five general functions of the mentor teacher: a) to inform: their primary function is to provide relevant and updated information, in the scope of supervision, observation and didactics, according to the teacher training objectives and needs, b) to question: must be able to problematize, questioning the reality that observes, equating the problems of practice and looking for alternative options c) to suggest: they should propose ideas, practices, solutions, motivate and encourage the realization of projects and classes for which both are responsible together d) to 
encourage: in the context of interpersonal relationships, as the affective load can influence the teacher's emotional balance, as well as his overall attitude towards the professional training process, e) to evaluate: mainly in its formative sense and not only of classification, being essential to the specification of the evaluation procedures.

Also, Alarcão and Tavares (1987) define some functions of the mentor teacher emphasizing: establishing and maintaining a good affective-relational climate, developing a spirit of reflection, self-knowledge and innovation, to plan the teaching-learning process of students and the teacher, to determine the aspects to be observed and establish observation strategies, to analyze and to interpret the observed data, to evaluate the teaching-learning processes and to define the action plans to be followed.

When we refer to the functions of the mentor teacher, we are also associating them with those of the university professor, as a guiding and consolidating element of the supervision process, despite its more punctual presence in cooperating schools, but accompanies and sustains in a complementary way in a more academic approach and future teachers. Levine (2011) also suggests two additional features that may be needed to promote best practice among teachers' educators: meet expectations and share information about their role and time frame for collaboration. In addition, a teacher who wants to lead others, should have or develop investigative and reflective skills, communication, interpersonal relationships, group work and problem solving, in a collaborative environment that allows construction and development in both teaching skills and leadership skills (Bond, 2011). Therefore, Mena et al. (2017) stated that it is important to bear in mind the skills that mentor teachers use in their practices, and to what extent their support can facilitate the acquisition of knowledge and professional development. They also concluded that supervisory skills can lead to effective reflective practice as long as the process is well defined and deliberately implemented through teacher training programs.

\section{Method}

Methodologically, this is a case study with participant observation, within the scope of the Master's Degree in Teaching Economics and Accounting of the Institute of Education of the University of Lisbon, the only master's degree in Portugal that gives the professional qualification for teaching in secondary education in Economics and Accounting. Upper secondary schooling in Portugal is grades 10-12 (age 16-18) and comes in several forms. As presented in Table 1, the most frequent one is high education (51.1\%) and vocational education and training (VET) courses $(36.2 \%)$ in 2018 based on the national database.

Table 1

Students Enrolled in Upper Secondary Education, by Forms of Education, in Portugal

\begin{tabular}{cccccccccc}
\hline Years & Total & $\begin{array}{c}\text { General } \\
\text { Courses }\end{array}$ & $\begin{array}{c}\text { \% High } \\
\text { education }\end{array}$ & $\begin{array}{c}\text { Professional } \\
\text { courses }\end{array}$ & $\begin{array}{c}\text { Apprenticeship } \\
\text { courses }\end{array}$ & $\begin{array}{c}\text { Technical } \\
\text { courses }\end{array}$ & $\begin{array}{c}\text { Vocational } \\
\text { courses }\end{array}$ & $\begin{array}{c}\text { \% VT } \\
\text { education }\end{array}$ & $\begin{array}{c}\text { Adult } \\
\text { education }\end{array}$ \\
\hline 2009 & 498327 & 195688 & 39.27 & 93438 & 13584 & 22039 & 4388 & 26.78 & 169190 \\
2012 & 411238 & 199321 & 48.47 & 113749 & 21056 & 12296 & 2012 & 36.26 \\
2015 & 393618 & 204105 & 51.85 & 114848 & 33030 & 5958 & 825 & 39.29 & 34852 \\
2018 & 401050 & 205016 & 51.12 & 116722 & 21869 & 6045 & 460 & 36.18 \\
\hline
\end{tabular}

Note. Source: DGEEC/ME-MCTES, PORDATA, https://www.pordata.pt/.

This master's degree is presented as a complement to the 1st cycle training, the Bachelor's degree, and aims to reinforce and deepen the initial scientific training, focusing on the knowledge necessary for teaching in these specific areas. Master's degrees in Teaching include disciplines in the specific scientific area of teaching, general educational area, specific didactics, cultural, social 
and ethical areas, and initiation into professional practice. In the context of the Bologna Process, the level of professional qualification for teaching became the master degree, particularly in Portugal. This increases the qualification of the teaching staff aimed at strengthening the quality of their preparation and enhancing their socio-professional status. The new system of professional qualification for teaching gives special value to the area of professional practice, as the privileged and irreplaceable moment of application of knowledge, skills, competences and attitudes to the real context. The study cycle of this Master course has a normal duration of 2 years in 4 semesters. The course includes the realization of a report carried out within the scope of supervised teaching practice with the respective presentation of the public defense act at the end of the fourth semester, developed in the Introduction to Professional Practice IV discipline.

The present study focuses on the identification and analysis of the main aspects in order to achieve a relationship of effective collaboration, reflection and practices sharing in the process of leadership and pedagogical supervision in the preservice teacher education through a qualitative methodological approach. In this approach, the criteria of validity (or credibility), transferability, trust and confirmation of knowledge construction were ensured (Guba, 1983), as well as the necessary analysis on ethical issues (BERA, 2011; Bogdan \& Biklen, 1994 ), also the Ethics Charter for Research in Education and Training of the Institute of Education, University of Lisbon was taken into account.

\section{Procedure}

The case study methodology is an approach that is well suited to research in education, where the researcher is confronted with complex situations in which it is difficult to select variables, but tries to describe and analyze a phenomenon and its interactions (Yin, 1994). The case studies, based on an inductive perspective and with participant observation, can be easily used as narratives of detailed analysis of a given context in real life, either as a pedagogical tool or as a research method (Grauer, 2012), in this case, the focus is on analyzing processes rather than results (Bogdan \& Bilken, 1994).

\section{Participants}

This study includes the participants of two classes from the last two academic years. As demonstrated in Table 2, 26 preservice teachers, 17 mentor teachers from different schools in different regions of the country and 4 university professors from HEI, located in Lisbon participated in this study.

Table 2

Research Participants

\begin{tabular}{|c|c|c|c|c|}
\hline \multirow{2}{*}{ Participants } & \multicolumn{2}{|c|}{ Number } & \multicolumn{2}{|c|}{$\%$} \\
\hline & Male & Female & Male & Female \\
\hline Preservice teachers & 15 & 11 & 57.69 & 42.31 \\
\hline Mentors teachers & 1 & 16 & 5.89 & 94.11 \\
\hline University professors & 2 & 2 & 50.00 & 50.00 \\
\hline
\end{tabular}

The preservice teachers of these two classes are $57.7 \%$ female and $42.3 \%$ male, with an average age of 41 years old, with the majority having professional experience in teaching (53.9\%). The vast majority attended the master's degree as a student-worker. This particularity is due to the fact that during a period of time there was no training offer for teachers in this scientific area in Portugal. This master's degree in Economics and Accounting Teaching was created in 2011. Of the 17 mentor 
teachers, only one is male, with the vast majority having extensive professional experience and a high age group. The schools, where the supervised practice works and developed, all include the secondary level and are distributed in various areas of the country with greater concentration on the Lisbon area. The supervised practice was carried out in regular education and in professional courses, $50.0 \%$ in each modality, in several courses and disciplines associated with the scientific areas of Economics and Accounting.

The four professors at HEI are all graduates in Economics or Management with a $\mathrm{PhD}$ in Education. In addition to the characterization of classes and contexts, through documentary analysis and interviews conducted by preservice teachers in the schools where they developed the supervised teaching process, data were collected through participant observation carried out by university professors. Field notes were made of these observations and also of informal meetings and interviews with mentor teachers, before and after observing classes in cooperating schools, with descriptive and reflective records, which allowed us to record the most subjective part of the observation and constitute a report of the course of the investigation (Bogdan \& Biklen, 1994).

\section{Instruments}

The important research instruments used were the assessment reports of the mentor teachers This was carried out throughout the master's disciplines and the supervised teaching practice reports that the preservice teachers developed and defended in a public presentation at the end of their supervised practice, as well as the observation process of classes. The observation was supported by the planning and pedagogical resources developed by the preservice teachers and the use of class observation grids and maps of participation and movements (of the master's students in the classroom) built and used for the purpose by both supervisors. As shown in Table 3, the observation grids contain a list of parameters associated in three groups: "Preparation and organization", "Accomplishment of the teaching activity" and "Pedagogical relationship with students", with a rating scale (from Insufficient, Regular, Good, Very Good, to Excellent or Not Observed) and two open fields, "Strengths" and "Improvement suggestions".

Table 3

Principals Parameters of Class Observation Grids

\begin{tabular}{ll}
\hline Preparation and organization & $\begin{array}{l}\text { Formulates objectives appropriately } \\
\text { Adapts strategies to students' learning } \\
\text { Selects suitable scientific and pedagogical materials }\end{array}$ \\
Accomplishment of the teaching activity & $\begin{array}{l}\text { Motivates students for the subjects } \\
\text { Encourages student participation and involvement in activities } \\
\text { Uses innovative educational resources }\end{array}$ \\
& $\begin{array}{l}\text { Uses an appropriate, clear and precise language } \\
\text { Managed class time correctly }\end{array}$ \\
& Favors a favorable environment for students' learning and participation \\
Pedagogical relationship with students & Supports and serves students according to their needs \\
Reveals balance in the exercise of authority
\end{tabular}

The evaluation criteria used include the scientific rigor of the concepts and content mobilized; the degree of content development; the organization, adequacy and coherence of the objectives, skills, content, methodology, strategies and resources in view of the context, objectives, intended learning and the expected time; clarity of presentation and correction of scientific language; promotion of discussion and/or critical thinking; pertinence and rigor of assessment methods and instruments; demonstration and promotion of innovation; incorporation of digital technologies in the teaching-learning process; and ability to reflect on their own practice. 
Data analysis was carried out through content analysis (Bardin, 2011; Flick, 2005). The data have been categorized, coded and processed, and still subject to triangulation by diversification of instruments and researchers, since the class' observation was carried out several times with a pedagogical pair of teachers, for attributing greater rigor to the collection and analysis of data (Denzin, 1984).

\section{Results}

The supervised teaching practice in the Master in Teaching of Economics and Accounting begins in the first year of the Master course, with visits by the preservice teacher to the school, interviews and observation of the work developed by the mentor teacher, which complement the seminars at the HEI. The second year is developed with the assistance and teaching of classes, allowing the Masters student almost complete control the role of the class teacher.

The work developed by preservice teacher seeks to appropriate knowledge and develop professional skills related to teaching practice, through planning, teaching, reflection and evaluation activities. This is supported by an investigation that is described in a final supervised practice report and in a field diary, thereby including a component of description and a reflective one.

Regarding the leadership and supervision process, observation of classes, generally by the mentor teacher, with some by the university professor, is one of the most important strategies used. This allows observation is conducted in a real context of skills development of teachers in training such as autonomy, relationship with students, reflective and collaborative capacity. On the other hand, this allows for the experience of being part of a leadership and supervision process, both essential for their personal and professional development.

In this process of class observation, summarized in Table 4, the guidelines of Reis (2011) were followed. The necessary procedures were developed so that before observing the classes of the preservice teachers, the mentor teacher clarified the objectives of the observation and discussed the following aspects: the rules for the observation, the integration of this class in the curriculum and planning, the objectives of the class, the strategy and possible evidence for its implementation, the possibility of differentiation in relation to some students, the dimensions of the observation, and also explained what they would do during the observation with date and time setting for the feedback meeting.

Table 4

Class Observation Process

\begin{tabular}{ll}
\hline Before class observation & $\begin{array}{l}\text { Clarification of the observation objectives and rules } \\
\text { Integration of this class in the curriculum and planning } \\
\text { Objectives and strategies to be used in the implementation of the class } \\
\text { Possibility of differentiation in relation to some students } \\
\text { Definition of the observation dimensions } \\
\text { Feedback meeting schedule }\end{array}$ \\
& $\begin{array}{l}\text { Minimize the presence of supervisors in the classroom } \\
\text { Record observations according to the established rules } \\
\text { Euring class observation }\end{array}$ \\
$\begin{array}{l}\text { Enroll impressions and questions for the feedback meeting } \\
\text { Reconstruct the events of the class together }\end{array}$ \\
$\begin{array}{l}\text { Discussion about was considered to have gone well in class } \\
\text { Reflection on what can be improved and on atypical situations } \\
\text { Analysis of observed behaviors that can be modified } \\
\text { Give constructive suggestions }\end{array}$ \\
\hline
\end{tabular}

During the observation, the supervising teachers sought to minimize their presence in the classroom, record their observations according to the established rules, and to record impressions and questions for the feedback meeting. At this meeting, following the defined procedures, they 
also tried to reconstruct the events of the class together with the preservice teacher, to ask him for a reflection on what he considers to have gone well in class, what he would like to improve and how, and to refer to possible atypical situations. Care was also taken to describe the observed behaviors instead of evaluating them, as these must be concrete and specific, focusing on behaviors that the preservice teacher has the capacity to modify, and finally, constructive suggestions were presented.

Based on the assessment reports of the mentor teachers, carried out by them at the end of each semester in the 2nd year, which include a qualitative and quantitative assessment of the totality of the work developed by the master's student, which encompasses, in addition to the classes observed and taught, participation in other activities of the school, with peers or students, there is a high commitment and participation of all preservice teachers. These assessment reports allow formal communication between supervisors, the recording of knowledge and skills developed by preservice teacher and, at the same time, are relevant tools to offer them formative feedback.

In the supervised teaching practice reports developed by the preservice teachers, we found in the vast majority mirrored in-depth reflections on their own practice, with different references to the support of mentor teachers and their contribution to their personal and professional training, revealing rigorous leadership and supervision processes that promote the development of their learning and skills.

\section{Discussion}

Regarding the supervision process, despite the evidence found in different contexts about the value of "clinical practice", its impact is mainly determined by the interaction between the various contributors (Levine, 2011). This study highlighted the importance, on the one hand, of seeking long-term partnerships with experienced teachers from cooperating schools for the training of future teachers, and on the other, the professional development and mentor teachers training, or ideally by the creation of supervisory teacher communities. In this way, clinical practice, in addition to the obvious effects on the preservice teacher education, can also be relevant in terms of its impact on the experienced professionals involved, namely in the benefits perceived by them, insofar as they are encouraged to be critically involved in sustained research perspectives when preservice teachers implement and evaluate their own practice (Burn \& Mutton, 2015).

According to Izadinia (2015), it was found that supervised practice can have a profound impact on teachers in their initial training, depending on the positive influence or lack of that, the leadership and supervision process is provided. This supervisory process should support the necessary link between theory and practice and allow the formation of professional identity. The functions of the mentor teacher analyzed in the literature review (Alarcão \& Tavares, 1987; Vieira, 1993) were verified in the supervision processes in this study. In addition to the general ones of informing, proposing ideas, practices and solutions, encouraging and evaluating, it was also found that it was possible to establish a good affective-relational climate, to offer support in planning the teachinglearning process, to agree on observation strategies, and to analyze and interpret the observed data. Considering the framing the leadership through partnerships in an educational context (Katzenmeyer \& Moller, 2009) and the leadership distributed between the university professor and the mentor teacher (Bond, 2011), the different types of leadership were observed by the supervisors.

Based on a predominance of servant leadership, it was found that mentor teachers as well as university professors supported preservice teachers according to their needs (Greenleaf, 1977). 
They sought to promote their personal and professional growth, through their valorization as people and by promoting shared leadership at the service of the followers for the good of each one (Laub, 2004), with the leader focusing mainly on the followers (Cerit, 2009; Stone et al. , 2004) and not much on the objectives or institutions. It is confirmed, therefore, that this type of servant leadership is feasible and appropriate to the educational context and specifically to that of pedagogical supervision in the preservice teacher education.

However, situations of transformational leadership were also observed in some cases, when the supervising teachers favored the construction and development of skills and innovative thinking based on a more open, dynamic culture that promotes change and innovation (Kaslow et al., 2012). The development of proactivity that allows teachers to act as agents of change (Fullan, 1993), such as it happens in organizations in general, can be applied in the context of pedagogical supervision, namely when we are preparing teachers for the future that will require from them the assumption of an active role and promoting innovation in schools.

It is clear that an organized and deliberate process of supervision and leadership can promote professional development and teacher satisfaction or be related to the results and progress of students (Ebrahimi et al., 2017; Zacharo et al., 2018). In this study, the experience of the shared leadership process between the university professor and the cooperating school teacher has a significant role in the enrichment of supervised practice. Furthermore, it increases learning and professional development and makes it possible to eliminate some underlying subjectivity within assessment, both formative and summative, and allows the preservice teacher to obtain feedback based on more than an insight and analysis than just a supervisor.

Throughout the process of leadership and pedagogical supervision that was developed, it was considered important to provide collaborative situations of teaching, assessment and learning, with individual and joint reflections in order to promote autonomy and shared interaction, which contributes to the professional development and building a base of shared knowledge between the various stakeholders, as the basic hypothesis of the study.

\section{Conclusion}

This research studied the pedagogical supervision process and the importance of shared leadership between the university professor and the mentor teacher, applied in a concrete case study based on a Master's degrees in Teaching at the University of Lisbon, taking into account the fundamental role of the mentor teacher from a cooperating school, who works in the field, in the process of collaborative supervision in preservice teacher education. Regarding the pedagogical supervision process, it was concluded that it is important for this process to create relationships and long-term partnerships with experienced teachers in the cooperating schools, but at the same time, it should be sought to promote the professional development and training of these mentor teachers, ideally, with the creation of supervisory teacher communities. In this way, supervised practice will have an impact both on the training of new teachers and on the professional development of mentor teachers, through experiences in which both engage in reflection, evaluation and critical analysis of praxis.

Another relevant conclusion was the awareness of the importance of the leadership process, complementary and interdependent with the supervision process at various levels; firstly, through the verified benefits of leadership distributed between two qualified supervisors for the production of qualitative feedback, essential in the preservice teacher education; secondly, the role that the 
leadership process offers in the construction of skills and professional development of all stakeholders. Concomitantly, it was concluded that the concept of leadership introduced in pedagogical supervision allows teachers in training to develop skills through the experienced process, offering them a shared leadership reference framework, with the consequent possibility of assuming leadership roles in the future. Thus, in order to prepare future teachers for these roles and responsibilities, it is important to introduce this concept of leadership in an educational context, offering them a mental structure to address these issues and allowing them to develop skills as leaders for certain tasks and activities they may be involved in their professional practice.

In short, regarding the leadership and pedagogical supervision in teacher education, we found the importance of observing the preservice teachers' classes, clarification of objectives and process, analysis and joint reflection on the events observed and suggestions for constructive improvement offered to future teachers, along with the possibility of professional development and the construction of skills at the level of leadership of all stakeholders in the process.

\section{Implication of the study and future research recommendation}

It is expected that this study, by addressing a very specific and little explored area of the leadership process in the preservice teacher education, will provoke a reflection on the importance and added value that this process can provide in the teacher's professional future and develop the leadership skills. It can also encourage the inclusion of leadership content in the curricula of initial teacher training courses.

Further research is required to explore the desirable possibility of developing research and training for more integrated, systematic and long-term mentor supervision, including the implementation of experiences of interaction and critical reflection supported by evidence, simultaneously with a set of continuous professional development actions (Aspfors \& Fransson, 2015). The qualitative meta-synthesis carried out by these authors, states that research should be guided in three comprehensive and interdependent dimensions: contextual, theoretical-analytical and relational. Models based on different assumptions about how to learn to be a mentor, result from efforts to interpret different types of relationships between mentor and preservice teacher and also from the construction of different types of contexts and the mentor teachers' own education. At the same time, it is also suggested to develop research on the needs for developing teachers' leadership skills, both in terms of their relationship with students, as well as in relation to colleagues, coordinators, principals and the various educational agents.

\section{References}

Alarcão, I., \& Tavares, J. (1987). Supervisão da prática pedagógica. uma perspectiva de desenvolvimento e aprendizagem [Supervision of pedagogical practice. A development and learning perspective]. Coimbra: Almedina.

Aspfors, J., \& Fransson, G. (2015). Research on mentor education for mentors of newly qualified teachers: A qualitative metasynthesis. Teaching and Teacher Education, 48, 75-86. https://doi.org/10.1016/j.tate.2015.02.004

Azevedo, J. (2012). Nota de apresentação [Presentation note]. Revista Portuguesa de Investigação Educacional [Portuguese Journal of Educational Research], 12, 3-5. Porto: Universidade Católica Editora, SA. http://www.fep.porto.ucp.pt/sites/default/files/files/FEP/RPIE/RPIE12NotaApresentacao.PDF

Bardin, L. (2011). Análise de conteúdo [Content analysis]. Lisboa: Edições 70, Lda. 
Batista, I. (2011). Ética, deontologia e avaliação do desempenho docente [Ethics, deontology and evaluation of teaching performance]. Lisboa: Ministério da Educação - Conselho Científico para a Avaliação de Professores. https://repositorio.ucp.pt/handle/10400.14/11641

BERA (2011). Ethical guidelines for educational research. London: British Educational Research Association. https://www.bera.ac.uk/publication/bera-ethical-guidelines-for-educational-research-2011

Berkovich, I. (2016). School leaders and transformational leadership theory: time to part ways? Journal of Educational Administration, 54(5), 609-622. https://doi.org/10.1108/JEA-11-2015-0100

Bogdan, R., \& Biklen, S. (1994). Investigação qualitativa em educação. Uma introdução à teoria e aos métodos [Qualitative research in education. An introduction to theory and methods]. Porto: Porto Editora.

Bond, N. (2011). Preparing preservice teachers to become teacher leaders. The Educational Forum, 75(4), $280-297$. https://doi.org/10.1080/00131725.2011.602578

Bowman, R. F. (2005). Teacher as servant leader. The Clearing House: A Journal of Educational Strategies, Issues and Ideas, 78(6), 257-260. https://doi.org/10.3200/TCHS.78.6.257-260

Burn, K., \& Mutton, T. (2015). A review of 'research-informed clinical practice' in Initial Teacher Education. Oxford Review of Education, 41(2), 217-233. http://dx.doi.org/10.1080/03054985.2015.1020104

Bush, T., \& Glover, D. (2014). School leadership models: what do we know? School Leadership \& Management, 34(5), 553-571. http://dx.doi.org/10.1080/13632434.2014.928680

Cerit, Y. (2009). The effects of servant leader ship behaviours of school principals on teachers' job satisfaction. Educational Management Administration \& Leadership, 37(5), 600-623. http://dx.doi.org/10.1177/1741143209339650

Denzin, N. (1984). The research act. Englewood Cliffs, NJ: Prentice Hall.

Ebrahimi, P., Chamanzamin, M. R., Roohbakhsh, N., \& Shaygan, J. (2017). Transformational and transactional leadership: Which one is more effective in the education of employees' creativity? Considering the moderating role of learning orientation and leader gender. International Journal of Organizational Leadership, 6, 137-156. https://ssrn.com/abstract=3333082

Flick, U. (2005). Métodos qualitativos na investigação científica [Qualitative methods in scientific research]. Lisboa: Monitor Projectos e Edições, Lda.

Forster, E. M. (1997). Teacher leadership: Professional right and responsibility. Action in Teacher Education, 19(3), 82-94. https://doi.org/10.1080/01626620.1997.10462881

Fullan, M. G. (1993). Why teachers must become change agents. Educational Leadership, 50(6), 12-17. https://www.semanticscholar.org/paper/Why-Teachers-Must-Become-Change-Agents.Fullan/86979d7a2934f42625651b1e1cea8a3af986c18e

Ginkel, G. V., Drie, J. V., \& Verloop, N. (2018). Mentor teachers' views of their mentees. Mentoring \& Tutoring: Partnership in Learning, 26(2), 122-147. https://doi.org/10.1080/13611267.2018.1472542

Grauer, K. (2012). A case for case study research in education. In S. R. Klein (Ed.), Action research methods (pp. 69-79). New York: Palgrave Macmillan. https://doi.org/10.1057/9781137046635 4

Greenleaf, R. K. (1977). Servant leadership: A journey into the nature of legitimate power and greatness. New York: Paulist Press.

Greenleaf, R. K. (2007). The servant as leader. In W.C. Zimmerli, M. Holzinger, \& K. Richter (Eds), Corporate ethics and corporate governance (pp. 84-94). Berlin, Heidelberg: Springer. https://doi.org/10.1007/978-3-540-70818-6_6

Guba, E. G. (1983). Criterios de credibilidad en la investigación naturalista [Criteria of credibility in naturalistic inquiry]. In J. S. Gimeno, \& A. P. Gómez (Eds.), La enseñanza: su teoría y su práctica [Teaching: theory and practice] (pp.148-165). Madrid: Akal.

Izadinia, M. (2015). A closer look at the role of mentor teachers in shaping preservice teachers' professional identity. Teaching and Teacher Education, 52, 1-10. http://dx.doi.org/10.1016/j.tate.2015.08.003

Kaslow, N. J., Falender, C. A., \& Grus, C. L. (2012). Valuing and practicing competency-based supervision: A transformational leadership perspective. Training and Education in Professional Psychology, 6(1), 47-54. https://doi.org/10.1037/a0026704

Katzenmeyer, M. H., \& Moller, G. V. (2009). Awakening the sleeping giant: Helping teachers develop as leaders, $3^{\text {rd }}$ Edition. Thousand Oaks, CA: Corwin.

Laub, J. (2004, August). Defining Servant Leadership: A Recommended Typology for Servant Leadership Studies. In Proceedings of the Servant Leadership Research Roundtable (pp. 607-621).

https://www.regent.edu/acad/global/publications/sl_proceedings/2004/laub_defining_servant.pdf

Levine, T. H. (2011). Features and strategies of supervisor professional community as a means of improving the supervision of preservice teachers. Teaching and Teacher Education, 27, 930-941. http://dx.doi.org/10.1016/j.tate.2011.03.004 
Lu, H. L. (2010). Research on peer coaching in preservice teacher education - A review of literature. Teaching and Teacher Education, 26, 748-753. http://dx.doi.org/10.1016/j.tate.2009.10.015

Maphalala, M. C. (2013). Understanding the role of mentor teachers during teaching practice session. International Journal of Educational Sciences, 5(2), 123-130. https://doi.org/10.1080/09751122.2013.11890069

Mena, J., Hennissen, P., \& Loughran, J. (2017). Developing pre-service teachers' professional knowledge of teaching: The influence of mentoring. Teaching and Teacher Education, 66, 47-59. http://dx.doi.org/10.1016/j.tate.2017.03.024

Muijs, D., \& Harris, A (2007). Teacher leadership in (In)action: Three case studies of contrasting schools. Educational Management Administration \& Leadership, 35(1) 111-134. https://doi.org/10.1177/1741143207071387

Pearce, C. L. (2004). The future of leadership: Combining vertical and shared leadership to transform knowledge work. Academy of Management Executive, 18(1), 47-57. https://doi.org/10.5465/ame.2004.12690298

Pearce, C. L., \& Conger, J. A. (2003). Shared leadership: Reframing the hows and whys of leadership. Thousand Oaks, CA: SAGE Publications. http://dx.doi.org/10.4135/9781452229539

Pearce, C. L. \& Sims, H. P. (2002). Vertical versus shared leadership as predictors of the effectiveness of change management teams an examination of aversive, directive, transactional, transformational, and empowering leader behaviors. Group Dynamics: Theory, Research, and Practice, 6(2), 172-197. https://doi.org/10.1037/1089-2699.6.2.172

Reis, P. (2011). Observação de aula e avaliação do desempenho docente [Class observation and teacher performance evaluation]. Lisboa: Ministério da Educação - Conselho Científico para a Avaliação de Professores. http://repositorio.ul.pt/handle/10451/4708

Stone, A. G., Russell, R. F., \& Patterson, K. (2004). Transformational versus Servant leadership: A difference in leader focus. Leadership \& Organization Development Journal, 25(4), 349-361. http://dx.doi.org/10.1108/01437730410538671

Vieira, F. (1993). Supervisão - Uma prática reflexiva de formação de professores [Supervision - A reflective practice of teacher education]. Rio Tinto: Asa.

Vieira, F., \& Moreira, M. F. (2011). Supervisão e avaliação do desempenho docente: para uma abordagem de orientação transformadora [Supervision and evaluation of teaching performance: towards a transformative orientation approach]. Lisboa: Ministério da Educação, Conselho Científico para a Avaliação de Professores. http://files.avaliacaoexterna.webnode.pt/200000021-b8fb0b9f74/Caderno_CCAP_1-Supervisao.pdf

Yin, R. (1994). Case study research: Design and methods, 2nd Edition. Thousand Oaks, CA: SAGE Publications. https://doi.org/10.1177/109821409401500309

Zacharo, K., Marios, K., \& Dimitra, P. (2018). Transformational leadership and job satisfaction: The case of secondary education teachers in Greece. Journal of Education and Training Studies, 6(10), 158-168. https://doi.org/10.11114/jets.v6i10.3451 